\title{
The Effect of Corporate Social Responsibility (CSR) on Corporate Image of Inna Grand Bali Beach Hotel Denpasar
}

\author{
Putu Riesta Permata Devi ${ }^{1, a, \#}$, A.A.Ayu Erna Trisnadewi ${ }^{1, b} \&$ I.B. Made Putra Manuaba ${ }^{1, c}$ \\ ${ }^{1}$ Department of Accounting, Faculty of Economics and Business, Warmadewa University, Denpasar, Bali, Indonesia \\ e-mail: ${ }^{\text {a\# }}$ ristapermata@gmail.com; ${ }^{\text {b }}$ dewierna236@gmail.com; ${ }^{\text {c }}$ ibmputra2117@gmail.com \\ ${ }^{\#}$ Corresponding Author \\ Whatsapp Number $\{+62-81944822418\}$
}

\section{ARTICLE HISTORY}

Received: 25 March 2019

Revised: 22 May 2019

Accepted: 11 July 2019

Copyright @ 2019 Authors \& Published by IIES Independent. This is an open-access article distributed under the terms of the CC-BY-SA License.

\section{ABSTRACT}

In accordance with Law No. 40 of 2007 concerning Limited Liability Companies and strengthened by Government Regulation Number 47 of 2012 which regulates the form of responsibility, especially in the social and environmental spheres that must be carried out by each company. This study aims to obtain empirical evidence of the influence of Corporate Social Responsibility (CSR) which is proxied into six indicators, which are community support, diversity, employee support, environment, non-territorial operations and product towards Corporate Image of Inna Grand Bali Beach Hotel Denpasar. The sampling technique was carried out by convenience sampling method. This study uses primary data in the form of a questionnaire measured by a Likert scale. The samples consist of 282 respondents.Multiple linear regression analysis was used. The results showed that community support had a positive effect on the Corporate Image of Inna Grand Bali Beach Hotel with a significance value of 0,000 . Diversity has a positive effect on the Corporate Image of Inna Grand Bali Beach Hotel with a significance value of 0,046. Employee support has a positive effect on the Corporate Image of Inna Grand Bali Beach Hotels with a significance value of 0,004 . Environment has a positive effect on the Corporate Image of Inna Grand Bali Beach Hotels with a significance value of 0,039 . Non-territorial operations have a positive effect on the Corporate Image of Inna Grand Bali Beach Hotels with a significance value of 0,024 and the product has a positive effect on the Corporate Image of Inna Grand Bali Beach Hotels with a significance value of 0,013 .

Keywords: Community Support; Diversity; Employee Support; Environment; NonTeritorial Operations; Product and Corporate Image

How to Cite: Devi, P.,R.,P., Trisnadewi, A.,A.,A.,E. \& Manuaba, I.,B.,M.,P (2019). The Effect of Corporate Social Responsibility (CSR) on Corporate Image of Inna Grand Bali Beach Hotel Denpasar. International Journal of Advances in Social and Economics, 1 (2), 45-51.

\section{Introduction}

Nowadays the tourism industry is experiencing increasingly rapid growth. In Indonesia, tourism is one of the most important industrial sectors. One of the favorite tourist destinations in Indonesia is Bali . This is because Bali has a variety of attractions that amaze tourists which include culture, tradition, art, and enchanting natural beauty. The growth of the tourism industry is followed by an increase in the number of supporting facilities for tourists who visit which are in the form of accommodation. One of these accommodations is a hotel. Hotel is a type of accommodation that uses part/all of the building to $\mathrm{pr}-$ ovide lodging, dining and drinking services that are managed commercially and meet the requirements regulations by the government.

The increasing number of hotels, of course, will increase the level of competition between these hotels. Each hotel will strive to formulate a strategy in order to survive and develop under the conditions of competition. One of them is to build a corporate image. One way to build a positive image is to do a Corporate Social Responsibility (CSR) program. In accordance with Law Number 40 of 2007 concerning 
Limited Liability Companies and strengthened by Government Regulation Number 47 of 2012 "Social and Environmental Responsibility of Limited Liability Companies" regulates the form of responsibility especially in the social and environmental spheres that must be or must be carried out by each company. CSR has a meaning as a tangible manifestation of social and environmental responsibility carried out by the company in achieving the company's long-term goals. Companies should carry out social responsibility consistently so that CSR activities are implemented, not only to help or minimize the negative impact of activities caused by the operation of the company, but can be used as a business strategy to get a positive response from the surrounding community.

The implementation of CSR in hotels will certainly have an impact on the company both now and later in the future. Inna Grand Bali Beach Hotel is a company that is in the middle of the community and has an obligation to carry out CSR programs in the surrounding environment. That is why the hotel seeks to establish positive and harmonious interactions with the community and the surrounding ecosystem environment. Both those relating to economic growth and the social environment of the surrounding community. Corporate Social Responsibility in this research is proxied into six indicators, which are, Community Support, Diversity, Employee Support, Environment, Non-Territorial Operation and Product.

\section{Literature Review}

\section{Stakeholder Theory}

Corporate social responsibility (CSR) is one of several corporate responsibilities to stakeholders (Solihin, 2009). A stakeholder approach emerged in the mid 1980. Freeman (1984) defines stakeholders as groups that can be influenced or influence the achievement of organizational goals. The background of the stakeholder approach is the desire to build a framework that is responsive to the problems faced by managers at that time namely environmental change. The aim of stakeholder management is to design methods for managing various groups and relationships that are produced in a strategic manner. The survival of a company depends on the support of stakeholders and that support must be sought so that the company's activities are to seek that support.

Stakeholder theory says that a company is not an entity that only operates for its own interests, but must provide benefits to stakeholders(shareholders, creditors, consumers, suppliers, government, society, analysts and other parties). Thus, the existence of a company is strongly influenced by the support provided by stakeholders to the company (Ghozali \& Chariri, 2007). One way to get stakeholder support, especially the community, is through CSR (Corporate Social Responsibility) activities. CSR activities are a form of company sincerity to set aside income earned to reduce the negative impacts that occur and try to maximize the positive impact of the company's operations on all interested parties. CSR arises since an era where awareness of the long-term sustainability of a company is more important than the income the company earns.

Indicators of the success of each business can be seen through two sides, namely the community and the company. For companies, public opinion on the company's image must be better in the eyes of the public. Whereas for the community there must be an increase in the quality of life. Companies that carry out social responsibility programs or CSR (Corporate Social Responsibility) consistently will receive broad support from communities that feel the benefits of their activities. The implementation of CSR will enhance a positive image in a long time and will establish a company's reputation and the public's view of the company is always positive.

\section{Legitimacy Theory}

Legitimacy Theory focusing on the interaction between the company and the community. This theory states that organizations are part of society so they must pay attention to the social norms of society because conformity with social norms can make the company more legitimate. Legitimacy is important for the organization, boundaries emphasized by social norms and values, and reactions to these constraints encourage the importance of analyzing organizational behavior with regard to the environment (Dowling and Pfeffer, 1975). CSR in Indonesia is regulated in Law No. 40 of 2007 concerning Limited Liability Companies. This law confirms that CSR has become the company's obligation. Article 74 paragraph 1 states that: "limited liability company that runs a business in the field and/ or concerned with natural resources must carry out social and environmental responsibilities." (Suharto, 2010: 19). Strengthened again in Law No. 25 of 2007 concerning Investment. Article 15 (b) states that: "Every investor is obliged to carry out corporate social responsibility." (Suharto, 2010: 20; Octavianus, 2019). Legitimacy theory explains that to keep getting legitimacy, company organizations must communicate environmental activities by making social environment disclosures. Environmental disclosures are considered 
useful to restore, improve and maintain the legitimacy that has been received.

\section{Research Method}

\section{Location and Object of Research}

The research was conducted in the area of Inna Grand Bali Beach Hotel, precisely in Sanur Kaja, Denpasar, Bali. The object of this research is Community Support, Diversity, Employee Support, Environment, Non-Territorial Operation, Product, and Corporate Image of Inna Grand Bali Beach Hotel Denpasar.

\section{Population and Sample Determination Methods}

In this study the population used was the people who live in Denpasar City near the Inna Grand Bali Beach Hotel with 7.893 people, 466 employees of the Inna Grand Bali Beach Hotel and 61.211 Guests of the Inna Grand Bali Beach Denpasar Hotel. The method of determining the sample used in this study is the Convenience Sampling method. The sample in this study was divided into three which are 100 Denpasar citizen, 82 of employees of the Inna Grand Bali Beach Denpasar Hotel and 100 guests of the Inna Grand Bali Beach Denpasar Hotel.

\section{Devinisi Operasional Variabel}

- Corporate Image is a reflection of the hotel identity that is formed from how the public viewpoint sees the company. The image is the company's main goal and at the same time is the reputation and achievement that will be achieved by the Inna Grand Bali Beach Denpasar Hotel. Although the definition of the image is abstract (intangible) and cannot be measured systematically, its form can be felt from the results of good or bad judgment.

- Community Support is the support given by Inna Grand Bali Beach Denpasar Hotel to the community. Community Support consists of support for educational, health and arts programs. The implementation of this program will certainly build a positive image of the company from the community.

- Diversity is the policy of Inna Grand Bali Beach Hotel to not discriminate consumers and workers in terms of gender, physical or certain races.

- Employee Support is in the form of protecting Inna Grand Bali Beach Denpasar Hotels to workers, providing incentives and awards and guarantee of work safety.
- Environment or environment is indeed inseparable from the company itself. The reciprocal relationship between the company and the environment itself connects it. The commitment of Inna Grand Bali Beach Hotel to create a healthy and safe environment, manage waste well and create environmentally friendly products will build a positive image of the company from the community.

- Non-Territorial Operations is how Inna Grand Bali Beach Hotels are responsible for giving equal rights to the world community to get employment opportunities, among others by opening abroad operations. In this study, it was adjusted to the condition of the company, considering that the company was only a national scale.

- Product is a matter that is closely related to the indicator environment, because from the use of product packaging that is friendly to the environment it will affect the environment itself. The Inna Grand Bali Beach Hotel is obliged to make programs that are safe for health, conduct research and development products in a sustainable manner and use packaging that can be recycled.

\section{Data Types and Data Sources}

The type of data used in this study is quantitative data. Quantitative data in this study were obtained from the number of values generated from the questionnaire distributed and answered by respondents. Based on the data source, the data used in this study is primary data. The primary data source is data obtained from the first source of each individual, such as the results of filling out the questionnaire. To obtain primary data the researcher conducted a questionnaire distribution to the community around the Inna Grand Bali Beach Hotel.

\section{Method of Collecting Data}

In collecting data for this study used methods of data collection by distributing questionnaires. Data obtained from the questionnaire will be processed using SPSS (Statistical Package for Social Sciences) but first it is necessary to test the instrument.

\section{Data Analysis Technique}

The data analysis technique used to solve the problem in this study is multiple linear regression. Multiple linear regression analysis techniques are used to determine the effect of independent variables on the dependent variable that is processed using SPSS 
(Statistical Package for Social Sciences). Before the multiple linear regression analysis, the classic assumption test is carried out first which includes the normality test, heteroscedasticity test, multicollinearity test, and autocorrelation test. After the classical assumption test is carried out then multiple linear regression analysis is conducted.

\section{Results and Discussion}

\section{Test of Research Instruments}

The provision of an instrument is said to be valid if it has a Pearson Product Moment correlation coefficient $(r)>0,3$ and is positive. The results of the validity test state that the instruments in all research variables, which are the variable Community Support, Diversity, Employee Support, Environment, Non-Territorial Operation, Product and Corporate Image have a pearson correlation greater than 0,3 so that the statement can be valid. Reliability Test is the degree of accuracy, and strength shown by the measurement instrument. Reliable means how much a measurement can be trusted. The value of an instrument is said to be reliable if the value of Cronbach Alpha is greater than 0,70. A questionnaire is said to be reliable if a person's answer to a statement is consistent or stable over time. The reliability test results state that the research instruments, which are the Community Support, Diversity, Employee Support, Environment, NonTerritorial Operation, Product and Corporate Image variables have an alpha cronbach coefficient greater than 0,70 so that the statement on the questionnaire is reliable. This means, if measurements are taken again with the same symptoms, then these measurements can provide consistent results.

\section{Classic Assumption Test}

The normality test in the study was carried out by the Kolmogorov-Smiarnov Test. Asymp.ig. (2-tailed) normality test results of 0,200 greater than 0,05 , it can be concluded that the multiple regression data model is normally distributed. The multicollinearity test shows the tolerance value for all variables greater than 0,10 and the VIF value is less than 10 , which means the regression equation model is free from the symptoms of multicollinearity. The results of the multicollinearity test show that the tolerance value of all independent variables is above 0,1 and the VIF value is below 10 so it can be concluded that the model has no symptoms of multicollinearity in this study. Heteroscedasticity testing in this study was carried out by plotting a graph between SRESID and ZPRED where heteroscedastatic disorders will appear with certain patterns on the graph. In this study shows the regression model of this study does not have heteroscedasticity disorders because it appears that dots that spread randomly, do not form a certain pattern that is clear, and spread both above and below the number 0 (zero) on the $\mathrm{Y}$ axis, this means no there is heteroscedasticity, so that a decent regression model is used to predict the dependent variable.

\section{Analysis of Multiple Linear Regression}

Table 1. Result of Analysis of Multiple Linear Regression

\begin{tabular}{|c|c|c|c|c|c|c|}
\hline \multicolumn{7}{|c|}{ Coefficients $^{\mathrm{a}}$} \\
\hline & \multirow[b]{2}{*}{ Model } & \multicolumn{2}{|c|}{ Unstandardized Coefficients } & \multirow{2}{*}{$\frac{\text { Standardized Coefficients }}{\text { Beta }}$} & \multirow[b]{2}{*}{$\mathrm{T}$} & \multirow[b]{2}{*}{ Sig. } \\
\hline & & $\mathrm{B}$ & Std. Error & & & \\
\hline \multirow[t]{7}{*}{1} & (Constant) & 14,970 & 3,555 & & 4,211 &, 000 \\
\hline & $\mathrm{X} 1$ & ,364 & 079 & 252 & 4,590 & 000 \\
\hline & $\mathrm{X} 2$ & , 186 & 092 &, 112 & 2,006 & ,046 \\
\hline & $\mathrm{X} 3$ & ,291 & , 100 & ,167 & 2,902 & ,004 \\
\hline & $\mathrm{X} 4$ & 197 & ,095 & ,113 & 2,072 & ,039 \\
\hline & $\mathrm{X} 5$ & ,308 & ,136 &, 124 & 2,271 & ,024 \\
\hline & $\mathrm{X} 6$ & 270 & ,108 & ,145 & 2,502 & 013 \\
\hline \multicolumn{7}{|c|}{ a. Dependent Variable: Y } \\
\hline
\end{tabular}

Based on the table 1, the multiple linear regression equations that can be formed are as follows:

$\mathrm{Y}=0,252\left(\mathrm{X}_{1}\right)+0,112\left(\mathrm{X}_{2}\right)+0,167\left(\mathrm{X}_{3}\right)+0,113\left(\mathrm{X}_{4}\right)+$ $0,124\left(\mathrm{X}_{5}\right)+0,145\left(\mathrm{X}_{6}\right)+\mathrm{e}$

The results of the multiple linear regression analysis above can be explained as:

\section{F Statistics Test}

Based on the results of the ANOVA test, the F value of 11,903 was obtained with a significance of $0,000 \mathrm{~b}<$ 0,05 . Based on the results of the $F$ statistical test, the model is feasible to be interpreted further or has fulfilled the goodness of fit. 


\section{T Statistics Test}

The results of the $t$ statistical test explain the effect of each independent variable individually on the depend ent variable.

- Community Support (X1) has a positive value of 4,590 with a significance level of 0,000 which is smaller than 0,05 so it can be concluded that Community Support has a positive effect on the Corporate Image of Inna Grand Bali Beach Hotel.

- Diversity (X2) has a positive value of 2,006 with a significance level of 0,046 which is smaller than 0,05 so it can be concluded that Diversity has a positive effect on the Corporate Image of Inna Grand Bali Beach Hotel.

- Employee Support (X3) has a positive value of 2,902 with a significance level of 0,004 which is smaller than 0,05 so it can be concluded that Employee Support has a positive effect on the Corporate Image of the Inna Grand Bali Beach Hotel.

- Environment (X4) has a positive value of 2,072 with a significance level of 0,039 which is smaller than 0,05 so it can be concluded that the Environment has a positive effect on the Corporate Image of the Inna Grand Bali Beach Hotel.

- Non-Territorial Operations (X5) has a positive value of 2,271 with a significance level of 0,024 which is smaller than 0,05 so it can be concluded that the Non-Territorial Operations has a positive effect on the Corporate Image of the Inna Grand Bali Beach Hotel.

- Product (X6) has a positive value of 2,502 with a significance level of 0,013 which is smaller than 0,05 so it can be concluded that the product has a positive effect on the Corporate Image of Inna Grand Bali Beach Hotel.

\section{Determination Coefficient Test}

The results of testing the coefficient of determination (R2) or adjusted $r$ square obtained the amount of $\mathrm{R}$ Square of 0,189 , which means that $18,9 \%$ of corporate image variation is influenced by variations in community support, diversity, employee support, environment, non territorial operations and products while the remaining $81,1 \%$ is caused by other factors outside the research model.

\section{Discussion}

Based on the results of data analysis, the influence of the community support variable shows a positive result of 0,252 with a significance level of 0,000 smaller than 0,05 . Based on this, the first hypothesis, the influence of Corporate Social Responsibility (CSR), which is proxied by community support, has a positive effect on the Corporate Image of the Inna Grand Bali Beach Hotel. The greater the support provided by Inna Grand Bali Beach Hotel on education, health and development programs and the assistance of facilities and infrastructure for the community, the greater the positive image that will be received by Inna Grand Bali Beach Hotel from the community.

Based on the results of data analysis, the effect of the diversity variable shows a positive result of 0,112 with a significance level of 0,046 smaller than 0,05 . Based on this, the second hypothesis, which is the effect of Corporate Social Responsibility (CSR) which is proxied by diversity, has a positive effect on the Corporate Image of Inna Grand Bali Beach Hotel. The better the policy implemented by Inna Grand Bali Beach Hotels and can commit to not differentiating consumers and workers in terms of gender, physical or certain races, the greater the positive image that will be received by Inna Grand Bali Beach Hotel.

Based on the results of data analysis, the effect of employee support variables shows a positive result of 0,167 with a significance level of 0,004 smaller than 0,05 . Based on this, the third hypothesis, which is the influence of Corporate Social Responsibility (CSR), which is proxied by employee support, has a positive effect on the Corporate Image of the Inna Grand Bali Beach Hotel. Employee Support is the protection of Inna Grand Bali Beach Hotels. For workers, providing incentives and awards as well as guaranteed work safety, the more safe and comfortable employees work at Inna Grand Bali Beach Hotels, the greater the positive image that will be received by Inna Grand Bali Hotels Beach.

Based on the results of data analysis, the effect of the environment variable shows a positive result of 0,113 with a significance level of 0,039 smaller than 0,05 . Based on this, the fourth hypothesis, namely the influence of Corporate Social Responsibility (CSR), which is proxied in the environment, has a positive effect on the Corporate Image of Inna Grand Bali Beach Hotels. 
Environment or environment cannot be separated from the company itself. The reciprocal relationship between the company and the environment itself connects it. The commitment of Inna Grand Bali Beach Hotel to create a healthy and safe environment, manage waste well and create environmentally friendly products will build a positive image of the company from the community.

Based on the results of data analysis, the effect of nonterritorial operations shows a positive result of 0,124 with a significance level of 0,024 smaller than 0,05 . Based on this, the fifth hypothesis, the effect of Corporate Social Responsibility (CSR) proxied by nonterritorial operations has a positive effect on the Corporate Image of Inna Grand Bali Beach Hotels. Non-territorial operations are how Inna Grand Bali Beach Hotels are responsible for giving equal rights to the world community to obtain employment opportunities, among others by opening abroad operations. Non-Territorial Operations in this study are adapted to the conditions of the company, considering that Inna Grand Bali Beach Hotel is only a national scale

Based on the results of data analysis, the effect of the product variable shows a positive result of 0,145 with a significance level of 0,013 smaller than 0,05 . Based on this, the sixth hypothesis, the effect of Corporate Social Responsibility (CSR) which is proxied by product has a positive effect on the Corporate Image of Inna Grand Bali Beach Hotels. Inna Grand Bali Beach Hotels are obliged to make programs that are safe for health, not deceptive, carry out research and product development on an ongoing basis and use packaging that can be recycled. This is closely related to the Environment indicator, because from the use of product packaging that is environmentally friendly it will affect the environment itself. This will be an advantage for the company because the creation of a clean environment will build a positive image of the company from the community.

\section{Conclusions}

Based on the results of the analysis that has been carried out, it can be concluded that Corporate Social Responsibility (CSR) which is proxied by Community Support, Diversity, Employee Support, Environment, Non-Territorial Operations and Product has a positive effect on Corporate Image of Inna Grand Bali Beach Hotel.

\section{Recommendation}

Based on the research that has been done, the suggestion that can be proposed is that it is expected to contribute to Inna Grand Bali Beach Hotels to further enhance CSR activities and publish CSR activities that have been carried out and in implementing CSR programs the company should be able to include documentation that can be published to the public extensive information about CSR activities carried out by the company. In addition, this study still has limitations in the use of variables. For further researchers, it is expected to be able to use or add other variables such as company reputation and branding of a company that has an influence on the emergence of Coroporate Image to be tested.

\section{References}

Arbashida, Febry \& Gunawan. (2016). Pengaruh Program CSR (Corporate Social Responsibility) dalam Mempertahankan Citra Positif di Lorin Hotel Solo. Jurnal Sekolah Tinggi Pariwisata Sahid Surakarta. http;//jurnal.stpss.ac.id

Atmadja, A.T \& K.A.K Saputra. (2017). Kajian Riset Akuntansi (Kuantitatif dan Kualitatif). Istiqlal Publishing Group, Singaraja

Ghozali, Imam. (2016). Aplikasi Analisis Multivariate Dengan Program SPSS edisi 8, Badan Penerbit Universitas Diponegoro

Ikhsan, A. (2009). Akuntansi Manajemen Lingkungan. Yogyakarta: Graha Ilmu.

Iswanto,Heri, Achmad Fauzi DH, Imam Rusadi. (2014). Pengaruh Corporate Social Responsibility Terhadap Citra (Studi Pada Warga RW 2, Kelurahan Panjang Jiwo, Kecamatan Tenggilis Mojoyo Kota Surabaya yang Tinggal Disekitar PT. Vitapharm). Jurnal Administrasi Bisnis (JAB), 13(1), Agustus 2014.

Mardikanto, Totok. (2014). Corporate Social Responsibility. Bandung: Alfabeta

Novarianto, Faris, Djamhur Hamid, M. Kholid Mawardi. (2017). Pengaruh Corporate Social Responsibility Terhadap Citra Perusahaan PT.Biersdorf Indonesia (Studi Kasus pada Pengunjung Merbabu Park Family Kota Malang). Jurnal Administrasi Bisnis (JAB), 42(2), Januari 2017.

Pemerintah Indonesia. 2007. Undang-Undang Republik Indonesia No. 40 Tahun 2007 tentang Perseroan Terbatas. 
Prasiska, Yosa Vega, Bunga Pertiwi , Yosi Rizky Nabila, Kristin Indah, Dian Safitri. (2017). CSR dan Citra Perusahaan (Survei Pada Warga Sekitar PT. Pandatex). The $6^{\text {th }}$ University Research Colloquium 2017 Universitas Muhammadiyah Magelang

Octavianus, S. (2019). The Cultivation of Indonesia's Education Financing Policy in Disruption Era. International Journal of Advances in Social and Economics, 1(1), 16-21.

Rahyuda, Ketut. (2016). Metode Penelitian Bisnis. Udayana University Press, Denpasar

Sugiyono. (2016). Metode Penelitian Kuantitatif, Kualitatif, dan R\&D. Penerbit Alfabeta, Bandung.

Tim Penyusun Kamus Besar Bahasa Indonesia. (2005). Kamus Besar Bahasa Indonesia. Jakarta: Balai Pustaka.

Triana, A. (2016). Pengaruh Penerapan Corporate Social Responsibility (CSR) Terhadap Citra Perusahaan BNI Syariah Cabang Yogyakarta. http://digilib.uin-suka.ac.id (Diakses pada tanggal 1 Agustus 2017).

Ulum, Bahrul, Zainun Arifin, Dahlan Fanani. (2014). Pengaruh Corporate Social Responsibility terhadap Citra (Studi Pada Warga Sekitar PT.Sasa Inti Gending-Probolinggo). Jurnal Administrasi Bisnis (JAB), 8(1), Februari 2014.

Ulva. (2012). Analisis Pengaruh Corporate Social Responsibility terhadap Citra Peusahaan (Studi Kasus PT International Nickle Indonesia Tbk). Skripsi tidakdipublikasikan: Universitas Hassanudin.

Vegawati, Silvania, Srikandi Kumadji, Dahlan Fanani. (2015). Pengaruh Program Corporate Social Responsibility (CSR) terhadap Citra Perusahaan (Survey pada Warga di Desa Sidodadi Kelurahan Kalirejo Kecamatan Lawang Kabupaten Malang). Jurnal Administrasi Bisnis (JAB). 20 (1), Maret 2015| Universitas Brawijaya

Widiyasari, N. (2015). Pengaruh Corporate Social Responsibility terhadap Corporate Image Nasmoco (Studi Kasus Warga Kota Semarang). https://media.neliti.com (diakses pada tanggal 1 Agustus 2017).

Widiatmika Andre. (2018). Pengaruh Corporate Social Responsibility (CSR) Terhadap Citra Perusahaan PT. Bank Rakyat Indonesia (Persero) Tbk (Survey pada Masyarakat Kota Denpasar). Universitas Warmadewa. 